\title{
INTERTEXTUALITY IN NOVEL: AN ESCAPE FROM PATRIARCHAL SOLILOQUY
}

\author{
Nargess Bagheri \\ Vali-e-Asr University of Iran, Iran
}

\begin{abstract}
Hypertextuality is one of the intertextual relationships introduced by Gerard Genette. According to him, hypertextuality includes all the relationships which the hypertext has with the previous text, i.e. the hypotext. However, he does not consider the relationship between these two texts to be in such a way that the hypertext is the interpretation of the hypotext. On the other hand, other theorizers including Bakhtin, regard the conversation between texts a way to escape a one-voiced and dominant discourse. From this viewpoint, the intertextual relationships of Sadegh Hedayat's The Blind Owl, with Shahrnoush Parsipour's The Blue Mind and Abbas Maroufi's The Body of Farhad are in such a way that The Blind Owl can be regarded as a hypotext for the other 2 novels but these two novels interpret the text differently. The present study aims to examine the intertextual relationships between these 3 novels and explore how a multiple-voiced conversation is formed between them.
\end{abstract}

Keywords: Intertextuality; Genette; Hypertextuality; Bakhtin, The Blind Owl; The Blue Mind and The body of Farhad 


\section{Introduction}

The Blind Owl, which can be regarded as the first modern Persian novel, has had a direct influence on the novels The Body of Farhad and The Blue Mind. This influence can be determined using intertextuality theory and identifying the intertextual relationships between the novels. The intertextual relationships between The Blind Owl and The Body of Farhad can be observed in the expressions, symbols and characters used in Hedayat's novel.

No research has been carried out into the intertextual relationships between The Blind Owl and The Blue Mind and only Abbas Milani has briefly referred to them in the introduction he has written to The Blue Mind (Refer to Milani, An Introduction to The Blue Mind, 1993, p. 27). In this novel, in addition to the structural and content-based similarities, with which the present paper deals, there can be found clear signs that Parsipour has been influenced by Hedayad.

On the other hand, intertextualiy is not just about being influenced and one of its most main issues is to find the reason for this relationship and to interpret it. From a feminist viewpoint, there are marked differences in the intertextual relationships of The Blind Owl with the other two mentioned novels. In what follows, after explaining the intertextuality theory and one of its main types, i.e. the relationship between the hypotext and hypertext, we will examine these differences.

\section{Hypertextuality}

One of the theorists in the field of intertextuality is the French critic Gerard Genette. He defines intertextuality as "the co-existence of two or more texts and the actualexistence of one text within another" $(1997$, p. 1).The fifth type of transtextuality which is the main subject of Genette's book Palimpsests is hypertextuality. From his viewpoint, "hypertextuality includes any relationship unitinga text $\mathrm{B}$ (we'll call it hypertext) to an earlier text A (we'll call it hypotext) and the relationship between these two texts is not in such a way that text $B$ is the interpretation of text A"(1997, p. 5, as cited in Allen, 2001, p. 156). Genette's primary argument about the relationship between the hypotext and hypertextis that the meaning of a hypertext depends on the reader's knowledge of the hypotext which the hypertext has humorously transformed or has imitated for the purpose of adaptation. As Genette shows, hypotexts may undergo the processes of expansion, extension and embellishment (ibid, pp. 156-159). One of the transformations of the hypertext is incentive transformation. As shown by Genette, transforming the incentive existing in the hypotexts can be the subject of groundbreaking studies. 
Hypertexts can give characters incentives which they lacked in the hypotext. They can also quell or annihilate an incentive existing in the hypotext (ibid, p. 160).

On the other hand, some feminist theorists have used interxtuality issues to present and expand their views. For example, Yaeger uses Bakhtinian dialogism to explain women's writing as a resistance against patriarchal monologism. This resistance is based on confirmation of "becoming-other" which is directly related to the assumptions of intertextuality and double-voiced discourse (ibid, p. 230). As Bakhtin states, identity is always achieved in relation to the Other (Allen, 2001, p. 144). According to Bakhtin, discourse constantly reflects class, group and national preferences and no word is neutral (Bakhtin and Volosinov, 1986, pp. 60-67). Unlike the single-voiced world which emphasizes the Self and selfishness and wants everything for itself and a totalitarian climate dominates it, the multi-voiced world stresses the Other and sees everything, even human life and entity, in the Other and dialogue with the Other (Gholamhosseinzadeh, 1999, p. 253).

Therefore, intertextuality is a way to create a multi-voiced discourse and escape the totalitarian climate and based on these opinions feminist theorists have found a way to evade the dominant patriarchal discourse. Show alter appears right to insist that theories about women's creativity need to take into account different combinations of discourse in women's writing because the best feminist writing will be created not by resisting but by conversing with the dominant ideologies that attempt to expel women's writing (Miller, 1997, p. 104).

Accordingly, if The Blind Owl can be considered a hypotext for the novels The Blue Mind and The Body of Farhad, while reading these two novels new systems of signifying should be taken into consideration and the incentives expanded, quelled and annihilated should be identified. The two novels in question, i.e., The Body of Farhad and The Blue Mind, take discourse positions different from that of The Blind Owl but Parsipour's method in The Blue Mind is quite different from Farhadi's in The Body of Farhad and it suggests that the female writer's discourse has been consistent with her female purposes. In what follows, we'll discuss it.

\section{The Intertextual Relationships of The Blind Owl with the Novels The Body of Farhad and The Blue Mind Woman}

It can be said that the main reason for the development of intertextual relationships between the three novels is the issue of woman. The Blind Owl has been widely examined in terms of its treatment of women. The novel's view of woman is extremist: In The Blind Owl woman is either ethereal and angelic or a 
whore and devilish. In her first appearance in The Blind Owl, woman is like an angel and the writer's primary concern is his inability to preserve this mental image. "No, I couldn't keep this passing beam for myself." (Hedayat, 1973, p. 10). The Blind Owl's narrator is unable to keep this beam and it is the very reason of his misery. In another scene when this woman enters the narrator's house and lies on the bed, the narrator is unable to understand her feelings: "Suddenly I felt that I was by no means aware of her heart's secrets and there was no relationship between us." (ibid, p. 19)

The second aspect of woman in The Blind Owl is "whore". This woman is also beyond the narrator's understanding and he cannot build a proper relationship with her and in the end kills her. Therefore, one of the main problems of the narrator in The Blind $\mathrm{Owl}$ is his inability to build relationship with women.

Unlike The Blind Owl in which the narrator is a man, the turning point in The Body of Farhad is that its narrator is a woman, a woman who from the painting on the pen case in The Blind $O w l$ has entered a different text and by existing the paint mode and finding corporeal presence in another time, has broken her silence. This very fact shows the significance of how women are viewed in the novel and because the narrator plays a key role in the story, this view reveals attention to woman's thoughts, emotions and feelings and since this narrator has exited the pen case described in The Blind Owl, it's obvious that she wants to recover her forgotten status and disclose what has been overlooked in The Blind Owl. The opposing character against woman in The Blind Owl is an old peddler who in The Body of Farhad changes to one of the minor characters that in different roles seeks to hurt woman and still lacks the ability to understand woman. In The Body of Farhad, the story's woman is the protagonist and the main hero. She seeks to find her beloved while the patriarchal society poses a big obstacle (Irani, 2013, p. 4). By choosing this narrator/woman, Abbasi has taken a big step to write a novel with female language and thought but in the end has only managed to show a part of woman's feelings, concerns and problems in different periods of history and the woman/narrator in his novel like the narrator in The Blind Owl is still unable to build relationship with the opposite sex. She has a deterministic and reactive spirit and from the outset considers herself subject to the fate which has been determined previously and has made her captive to the patriarchal society from infancy (Irani, 2013, p. 6).

Woman in Maroufi's novel still has the two aspects of etherealness and whoreness of the hypotext The Blind Owl and finally at the end of her vain pursuit of her beloved, she says, "There was no one, there was no answer, the room smelt of death, of swollen corpse in a suitcase on the shoulder of a woman..." (Maroufi, 2005, p. 137). She, like The Blind Owl's narrator, fails to build relationship with and reach the beloved. 
The Blue Mind, as Milani states, somehow includes all the previous works of Parsipour. In this novel, transforming the incentive in the hypotext The Blind $O w l$ gives the male and female character incentives that Hedayat's novel lacked. In this novel, woman acts as a proactive character. According to Milani, in relation to men, the story's heroine is always superior or at least equal to men. She reads men's minds, knows the future and understands the past, cannot be humiliated and is by no means submissive (Milani, 1993, p. 20). Moreover, in The Blue Mind, the boundary between being ethereal and being whore blurs.

The captain in The Blue Mind states the main reason of his evading woman as follows: "You know I always like to see women delicate and fragile. You damage this image in my mind. Although you look both delicate and fragile, there's something that disturbs me... I think you want to take my manly powers." (Parsipour, 1993, p. 520). However, the woman tries to give a satisfactory answer: "I'm not as horrible as you think and I ensure you that I don't intend to take your manly powers at all. In fact, a world without man is a terrifying world. On the contrary, I wish you to be the most powerful man in the world but a man for the present and future not the past" (p. 521). In this novel, the writer considers human to be binary, man/woman, and believes the progress of both is necessary for the advancement of human society (Refer to Parsipour, 1993, pp. 520-522). And in this way the writer attempts to blur the boundaries and create mutual understanding between man and woman.

\section{Image}

In The Blind Owl there is a central image that is fully described once and then its elements are repeated frequently and sparsely throughout the story. "All the day I was occupied painting on pen cases." (Hedayat, p. 12) "What is strange, however, and what is incredible is that, for some reason, the subjects of all my painted scenes have been of the same type and shape. It always consists of a cypress tree at the foot of which was squatting a bent old man like an Indian fakir. He had a long cloak wrapped about and wore a turban around his head. The index finger of his left hand was pressed to his lips as a gesture of surprise. Opposite him stood a girl in a long black dress, leaning towards him and offering him a morning glory flower. She was leaning because between them ran a stream." (ibid)

The woman in The Body of Farhad is this very woman in Hedayat's painting who exists the pen case and loves her painter. In The Body of Fathad, Maroufi repeats this scene by giving a new significance to the external structure in The Blind Owl and using its elements. This image contributes to the development of the story in a way different from what it does in The Blind Owl. The last image in The Body of 
Farhad is as follows:

"Someone took the suitcase on my shoulder and went away. Wasn't there a corpse on my shoulder anymore?... The dogs were barking in the distance and near a stream under a cypress tree a bent old man had his finger pressed to his lips as a gesture of surprise, waiting for me to pick a morning glory flower and offer him. Isn't it sad?" (Maroufi, p. 139). In this image, the man and woman are still standing away from each other and the man is waiting for the woman to offer him a flower and this suggests that there's no relationship between them.

The same image has been used in The Blue Mind. The Woman said, "I used to go into to the closet. I knew there was an opening in there. There was also a stream, and a tree. Then, I used to stand under the tree, put my index finger into my mouth and bite it" (Parsipour, p. 239). This image plays a significant role at the end of The Blue Mind. When the woman and captain go to a photographer to have their photo taken, the woman asks for a background for the photo and the photographer brings this very image: "Woman told the captain, "I'll go to the painting, to the other side of the stream. You sit this side in a way that your body covers the old man so that he won't be in the photo. Then, I'll offer you a flower and you'll take it from me, posing you're taking it from me (ibid, p. 538). Hence, the woman returns to her place and the captain takes the place of the bent old man and the flower of morning is replaced by a broom. In the closing pages of the book, the woman steps into the painting and the man reaches a new level of self-awareness. Parsipour finds a different function for this image. Shegives the old man's youth back to him and concludes the story differently.

\section{Morning Glory Flower}

In the hypotext The Blind Owl, morning glory flower is one of the main symbols of the story and the ethereal woman is offering a flower to the old peddler. In the hypertext The Body of Farhad, this image is repeated. Therefore, if the morning glory flower is a symbol of love, the girl's love does not work. "The painter dropped her brush and said "It's ridiculous. I tried to return to my earlier state but the morning glory flower had slipped out of my hand and the stream had taken itaway" (Maroufi, p. 8).

In the hypertext The Blue Mind, the morning glory flower makes the woman upset and angry. In this novel, like the novel The Blind Owl, the woman can't give the morning glory flower to the old man. However, Parsipour's impression of the 
morning glory flower is different from that of The Blind Owl and The Body of Farhad. She somewhere considers the flower a feminine symbol which is intertwined with the soul of nature (Parsipour, p. 433). In the last scene of The Blue Mind, when the captain takes the place of the bent old man, he wants to take the flower but his hands are busy with the broom which the woman has previously given him. "The captain said hastily, "The flower...What'll happen to the flower?" The woman replied, "Don't you see. Your both hands are busy with the weapon (broom)." (Parsipour, p. 538) Hence, the morning glory flower loses its function and changes to a broom with which the man has to clean his mind, the house, alley and city and step into a new world.

\section{Killing/Chopping}

Killing is one of the man incidents in The Blind Owl. At first, when the ethereal woman comes to the narrator's house and dies there, the narrator chops her (Refer to Hedayat, p. 28). The narrator kills the whore too and hence loses both the two aspects of woman. Elsewhere, the old peddler is the very hearse man who takes the woman's body to the graveyard.

In The Body of Farhad, the man comes to the woman's house and this time he dies on the bed. The Body of Farhad's narrator, like The Blind Owl's, chops the corpse and puts it in a suitcase and he faces an old hearse man too. Instead of burying the body of the beloved near the Shah Abdol Azim Shrine or somewhere else similar to it, which occurred in The Blind Owl, the woman goes to the train station with the help of the bent old man and gets onto the train. Until the end of the story, the train keeps moving towards an unknown destination, sometimes quickly, sometimes slowly and sometimes it stops and the woman throughout all her life, unsuccessful in his attempt to find her beloved, only carries his body on her shoulder (Maroufi, p. 82). At the end of her pursuit, in front of hedayat's house, she soliloquizes about the agony of not finding the beloved (Hedayat, p. 137). This woman is the vey painting model whose whore aspect attends the painter's house and the story's present time and chops the story's whore painter (ibid, pp. 85-86) (cited by Eskandari, 2013, p. 225).

In The Blue Mind we observe a transformed function. In this novel, after the description of the woman's promiscuity, the captain sees a guerrilla, which is a symbol of masculinity, goes towards the woman to cut off her head. The guerilla chops the woman with a sword and the captain chops the guerilla and finds out that he has no reproductive organ. Meanwhile the woman tells him, "This is the comeuppance for a man who not only does not love his anima but also kills her, puts 
the most terrible words and sentences into her mouth without asking himself why does she behave like this?; why has she become a whore?; why has she forgotten the picture of the morning glory flower that she had kept in mind since the beginning of life?" (ibid, p. 263) In this way, new concepts and meanings different from those of the hypotext are formed in The Blue Mind. Then, the writer describes the result of using these themes and shows how she has employed The Blind Owl's incidents to convey her desired concepts and meanings: "The man who has suffocated his anima to gain control over her has inevitably suffocated the creator of his thoughts, of course if he has suffocated her. However, if he chops her, he has definitely chopped the creator's thoughts and can only present them as scattered fragments." (ibid, p. 531)

From chopping, the old peddler, the writer's actions in The Blind Owl and their relationship toanother story Hedayat, i.e. Mistress Alaviyeh (Alaviye Khanom), The Blue Mind's writerin a coherent context draws the general conclusion that killing and chopping are the main reason for the man/narrator's loss of creativity and castration (ibid, pp. 278-279).

\section{Youth and Old Age}

The narrator in The Blind Owl is in fact the same old peddler who has lost his youth. Similarly, in The Body of Farhad, the man is simultaneously both a child and a man and experiences different ages.

Likewise, in The Blue Mind, this theme like the other ones previously mentioned, finds a different function. The man in The Blue Mind is a young and handsome captain that after distancing himself from his anima, loses his youth apparently. "The captain liked to go to the streets to look for his youth. He thought if he wouldn't find the street, he'd go towards the graveyard. He might find the closet, the woman and that old man. The captain thought if he'd see the old man again, he'll feel well. He might be able to take his youth back from the old man (Parsipour, p. 253). This old man is the same bent old man in The Blind Owl who's taken the captain's youth. Parsipour believes that the reason for The Blind Owl's getting old and infertility is that he chopped and killed his anima (ibid, p. 355). In fact, everything from The Blind Owl reflected in The Blue Mind has created a dialogue and has been replied by the female writer. 


\section{Conclusion}

The novel The Blind Owl is a hypotext for the two novels The Body of Farhad and The Blue Mind. Many of its themes can be found in these two novels. In their intertextual relationships with the novel The Blind Owl, both the two novels The Body of Farhad and The Blue Mind have restructured the text but the method adopted by the male writer, i.e. Maroufi, is different from that of the female writer, i.e. Parsipour. In accordance with the notion of dialogism introduced by Bakhtin as a way to escape the dominant discourse, Parsipour has expanded her female thoughts by creating a dialogue with The Blind Owl. In Maroufi's novel, man and woman continue to stay away from each other and there's distance between them. However, in The Blue Mind, they come to a relative understanding of each other. In The Body of Farhad, the woman is the narrator and reveals her feminine emotions and feelings and relates the story of her own life but most of the themes adapted from The Blind Owl are used in the same way. In The Blue Mind, the morning glory flower finds a different symbolic function; being chopped, youth and old age are transformed in meaning and described and the captain takes the place of the old peddler and attempts to leave the previous mental world which is based on lack of understanding of woman and reach a new understanding.

\section{References}

Akbari Beiragh, H. \&Ghorbanian, M. 2002. The Narrative Time in the Novel The Body of Farhad. The Scientific Research Quarterly of Literary Criticism 5(18): 7-24

Allen, G. 2001. Intertextuality. Yazdanjou, P. (Trans). Tehran: Central Publication.

Bakhtin, M. M \& V. N. Volosinov. 1986. Marxism and the Philosophy of Language. L. Matejka\& I. Titunik (Trans.). London: Harvard University Press.

Beigi, R., Mohammad Irani, M. \& Ghorbanian, M. 2012. (Intertextuality and Vicious Circle: 2 Postmodern Elements in Maroufu's Novel The Body of Farhad. The Scientific Research Quarterly of Literary Criticism 5 (20): 121-142

Darabi, B., Heidari, F. \& Amani, B. 2013. Intertextual Interpretation of The Body of Farhad and The Blind Owl. The Scientific Research Quarterly of Literary Criticism 6 (22): 67-88

Eskandari, A. A. \& Javadi, S. 2013. A Comparative Study of Narration in Hedayat's The Blind Owl and Maroufi's The Body of Farhad. Bahar Adab Journal 3 (2): 211-229

Ferber, M. 2001. A Dictionary of Literary Symbols. Cambridge: Cambridge.

Genette, G. 1997. Palimpsests: Literature in the Second Degree. Channa Newman \& Clude Doubinsky (Trans.) London: University of Nebraska Press. 


\section{N. Bagheri}

Genny, L. 1982. “The Strategy of Form” in T. Todorov (Ed.) French Literary Theory Today: A Reader: Cambridge: Cambridge University Press :34-36.

Gholamhosseinzadeh, G. R. 2008. The Presence of a One-voiced and a Multiple-voiced World in Hafez's Poetry. Shahid Beheshti University's Journal of Humanities 1 (57): 235-256.

Hedayat, S. 1937. The Blind Owl. Tehran: Mohammad Hassan Elmi's Publication.

Irani, M., Mirzabeigi, M. \& Ghorbanian, M. 2013. Round Characterization in Maroufi's The Body of Farhad. Contemporay Persian Literature Journal 3(4): 1-18

Maroufi, A. 2005. The Body of Farhad. Tehran: Ghoghnous Publication

Namvar Motlagh, B. 2008. Dialogism and Multi-voicedness: An Investigation of Bakhtinian Hypointer-textuality. The Journal of Philosophy and Speech: Cognition Spring (57): 397-414.

Parsipour, S. 1994. The Blue Mind. Switzerland: Baran Publication. 